\title{
Encouraging Creativity with Scientific Inquiry
}

\section{Lloyd H. Barrow}

University Missouri Science Education Center, University of Missouri, Columbia, USA.

Email: BarrowL@Missouri.edu

Received March 10 ${ }^{\text {th }}, 2010$; revised April 25 $5^{\text {th }}, 2010$; accepted June $2^{\text {nd }}, 2010$.

\begin{abstract}
Creativity facilitates scientists in their investigations of new problems or with a new orientation. However, K-12 science education typically does not acknowledge this aspect of creativity. Science/Technology/Society provides an avenue for creativity when addressing inquiry. The use of Cothron et al.'s [1] four question strategy allows for a planning approach for inquiry.
\end{abstract}

Keywords: Science, Inquiry, K-12

The majority of the use of creativity today is in the arts and humanities. Kind and Kind [2] consider creativity has greater identity with art rather than science. However, numerous famous scientists such as Charles Darwin, Charles Lyle, Galileo, Isaac Newton, Watson and Crick, Albert Einstein, and many others are recognized for their creativity associated with ways of scientific discovery. According to Root-Berstein and Root-Bernstein [3], it was originally assumed that artists and scientists had approached things in different ways, concluding that scientists use similar processes as artists in their creative endeavors because both types of individuals have broad interests, similar psychological profiles, similar creative habits, and art can influence scientific discovery and vice versa. The influence of Snow's "The Two Cultures" [4] fosters this assumption. Others consider the arts to be evaluated by intrinsic aesthetic criteria while science is evaluated by the contributions to systems of truth (i.e. scientific laws, scientific theories, etc.) [5]. Creative thinking is the production of novel or aesthetic ideas or products which would include both art and science [6]; however, it is considered that science has an indirect connection with creativity [7].

\section{What is Creativity?}

Just as there are different views of careers associated with creativity, there are multiple definitions. Gardner [8] defined creativity where products developed are viewed as novel within the discipline/specialty and are ultimately accepted within the community. Gardner's definition separates experts and creativity with creative individuals being superior. Gardner considers creativity in physics different from creativity in the non-sciences. A creative individual takes risks, is not afraid of failing, seeks the unknown, or questions the status quo. Gardner also concurs with Czikszentmihalyi [9] that creativity comes from the interaction of special talented individuals, discipline and others in the field who will make judgments about the quality and originality. Creativity also involves the discipline of being ready and willing to accept the creative contribution [10]. For example, Gregory Mendel's work on the genetics of peas in 1863 was not acknowledged until the 1900's. This creative link was originally missed for close to 40 years. Mendel had sent his paper to Darwin but it was never opened until his papers were recently put on the web.

Plucker et al. [11] identified three aspects in defining creativity:

1) Frequently involved more than one individual,

2) Happens when applied in a supportive environment, and

3) Results in new and useful identifiable product for society

Plucker [12] summarized 100 years of research on creativity. Throughout this paper, creativity involves novel products/approaches formulated by teams that result in a possible solution to part of a problem or benefit to society. Students have novel approaches to problems they encounter in K-12 and frequently demonstrate aspects of creativity that is appropriate for their leveltheir personal inquiry.

What makes science unique and where does creativity fit? Just like many careers, future scientists follow a formal and structured apprenticeship - doctorate where research occurs under close supervision by an expert mentor, post-doctoral study where an individual hones their skills and insight. Their minds are challenged to extend 
knowledge as new experts. Their interaction with peers at conferences and professional reading facilitates their creative approach. This occurs in a laboratory or field site with controlled variables where data are collected to resolve a testable question. Other times the sequence is to collect and analyze data, hypothesis and conclusion/ next question because the discipline is unable to control variables.

The greatest scientists think of new questions that have not been previously considered [13]. Scientists utilize both deductive reasoning (implications formed from general assumptions) and inductive reasoning (general principles from individual phenomena). Gardner [13] acknowledges that science is a social invention and is dependent upon society accepting the consequences (e.g. current debate over global warming).

The goal of science is the mastery of one of the disciplines conceptual schemes [14]. As new scientists refine their skills, previous research reports provide clues of possible new approach and things to avoid. Science is built upon previous results. Koestler's book on creativity and science [15] noted the process of combining previously unrelated knowledge which results in new relationships. Scientists also use visualization to help form a solution (e.g. Watson's description of DNA spiral), analogy and logic to help resolve their question by bringing realization to their idea-either acceptance or rejection. John-Steiner [14] summarized:

“... scientist's training allows him or her to test the value of an insight....for its general concepts. And in the process of testings, other, more complex analogies or disturbing patterns emerge... At times the struggle with an idea is incredibly lengthy".

However, this image of science is not accurately portrayed in K-12 science classrooms of the United States. Investigations are short duration, typically verify what has been studied, cookbook orientation, and purpose is not understood by students [16]. According to Cschszentonhalyi, Rothende, and Whalen [5], K-12 science has a focus on discipline work where lessons are sequenced with logical steps. Scientists and secondary science teachers agree it is important to include critical thinking skills and lessons should inspire students' creativity [17].

\section{Creativity and STS}

So how can we get K-12 students involved in the creative approach in science? Hodson and Reid [18] consider creativity to be integral to science and the scientific process. Creativity is one of the five components of the Science/Technology/Society (STS) movement [19]. Yager and Roy [20] conclude that STS facilitates students' creativity by encouraging K-12 students to ask more questions in their development of science concepts, encourages the development of unique questions of personal interest, investigates causes and effects of their personal observations, and generate more high quality questions associated with their personal lives. The key focus of STS instructional model is the selection of a long term problem where students take an action to attempt to resolve part of the problem. The problem is motivational to the students and tends to be a local problem. Creativity occurs as students investigate various aspects of the problem. Science/technology/society is an international movement.

Students' views of science are shaped by their school experiences; therefore, it is imperative to engage K-12 students to promote more positive attitudes toward science and improve their creativity skills [20]. STS is not a prescriptive approach of science teaching, but involves problem driven activities which begins with a problem or situation that is appropriate and relevant to the students [21]. Cschszentonhalyi [5], and Penick [22] consider question-posing and problem-finding are at the heart of originality; thereby, strongly associated with creativity. Creative approaches are not by chance [22]. To promote creativity, Penick recommends thought provoking questions where students can explore, take risks, experiment and speculate in a safe environment. Lee and Erdogan [23] studied 591 Korean students of STS trained science teachers and found they had a significantly higher creativity score over a control group. The creativity test focused upon three areas-questioning, reasoning, and predicting consequences. Lee and Erdogan described an STS learning environment where students are active participants in dealing with real-world problems. In addition, STS students had a more positive attitude toward science.

\section{Inquiry}

In the United States, the focus of K-12 science education of the 1990's was shaped by the publication of two policy documents-Science for All Americans [24] and $\mathrm{Na}$ tional Science Education Standards, NSES [16]. Both of these documents stressed the importance of inquiry. However, inquiry today is approached differently than from previous generations [25]. NSES identified three aspects of inquiry - abilities, understanding and teaching. The first domain-abilities of inquiry require K-12 teachers of science to provide multiple investigations for students that are not verification or "cookbook" laboratory experiences. The second domain is understandings about inquiry so students will develop meaning about science and how scientists work. The final domain is teaching where various strategies (e.g. wait time, assessing prior knowledge, effective questioning strategies, long term investigations, etc.) would facilitate students' understanding of science [25].

The National Research Council [26] clarified inquiry by identifying five attributes for learners:

1) Engages in scientifically oriented questions,

2) Gives priority to evidence in responding to ques- 
tions,

3) Formulates explanation from evidence,

4) Connects explanations to scientific knowledge, and

5) Communicates and justifies explanations.

These five attributes are on a continuum from teacher directed on one end to student directed on the other end. Therefore, a K-12 teacher of science can rate their teaching approach, curriculum, and assessment for level of inquiry. Table 1 from National Research Council [26], illustrates variations that a teacher of science can utilize in their use of inquiry. The degree of teacher-student centeredness can vary for each attribute.

Several researchers have developed categories of inquiry based upon the responsibilities of the student and teacher. Earlier, Swaab's [27] classified inquiry into four levels for source of question, data collection methods and interpretation of results. For level $\mathrm{O}$, the teacher provides students with the testable question to be investigated, methods for collecting data, and guides them toward the expected conclusion. This would represent a "cookbook" type investigation. A Level 3 would involve students framing the question, devising the procedures to gather the data, and formulating conclusions based upon the data. Coburn [28] considers this to be an open inquiry similar to what a student would do for a science fair project. Coburn considers Schwab's Level 1 and 2 to be guided inquiry. Settlage [29] has argued that it is illogical for K-12 science to have an open inquiry focus. Johnston [30] has recently challenged this view. The science education community has not resolved the emphasis of inquiry because of confusion about what is inquiry [25]. It must be noted that the NSES [16] did not recommend that all science concepts be taught by inquiry. For a different investigation, teachers of science could have different emphasis.

The use of all three domains of inquiry will facilitate students' creativity. What are some inquiry strategies teachers of science can utilize to facilitate creativity? First, students need to have opportunities to design scientific oriented investigations through their testable question. Second, students would work in small groups as they design their procedures to address the question. Third, students will share their findings with peers. Some students will create a formal presentation, poster, and/or technology report. Kind and Kind [2] considers inquiry as described mimics scientists use of creativity.

The use of the four question strategy [1] allows students from elementary through graduate school to implement a format that can be used to address their personal testable question. These four questions are:

1) Available materials?

2) Different forms of materials?

3) What will be modified in attempting to answer the question?

Table 1. Essential features of classroom inquiry and their variations

\begin{tabular}{|c|c|c|c|c|}
\hline Essential Feature & \multicolumn{4}{|c|}{ Variations } \\
\hline $\begin{array}{l}\text { Learner engages in scien- } \\
\text { tifically oriented ques- } \\
\text { tions }\end{array}$ & Learner poses a question & $\begin{array}{l}\text { Learner selects } \\
\text { among questions, } \\
\text { poses new questions }\end{array}$ & $\begin{array}{l}\text { Learner sharpens or clari- } \\
\text { fies question provided by } \\
\text { teacher, materials, or other } \\
\text { source }\end{array}$ & $\begin{array}{l}\text { Learner engages in ques- } \\
\text { tion provided by teacher, } \\
\text { materials, or other source }\end{array}$ \\
\hline $\begin{array}{l}\text { Learner formulates ex- } \\
\text { planations from evidence }\end{array}$ & $\begin{array}{l}\text { Learner formulates ex- } \\
\text { planations after summa- } \\
\text { rizing evidence }\end{array}$ & $\begin{array}{l}\text { Learner guided in process } \\
\text { of formulating explana- } \\
\text { tions from evidence }\end{array}$ & $\begin{array}{l}\text { Learner given possible } \\
\text { ways to use evidence to } \\
\text { formulate explanation }\end{array}$ & $\begin{array}{l}\text { Learner provided with } \\
\text { evidence }\end{array}$ \\
\hline $\begin{array}{l}\text { Learner communicates } \\
\text { and justifies explanations }\end{array}$ & $\begin{array}{l}\text { Learner forms reasonable } \\
\text { and logical argument to } \\
\text { communicate explana- } \\
\text { tions }\end{array}$ & $\begin{array}{l}\text { Learner coached in devel- } \\
\text { opment of communication }\end{array}$ & $\begin{array}{l}\text { Learner provided broad } \\
\text { guidelines to sharpen } \\
\text { communication }\end{array}$ & $\begin{array}{l}\text { Learner given steps and } \\
\text { procedures for commu- } \\
\text { nication }\end{array}$ \\
\hline \multicolumn{5}{|c|}{ 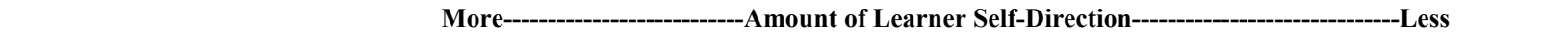 } \\
\hline \multicolumn{5}{|c|}{ Less-----------------Amount of Direction from Teacher or Material--------------------More } \\
\hline
\end{tabular}


4) How will its impact be measured?

This approach allows students a consistent approach for planning their investigation including identifying and controlling variables. Different groups of students could use different creative ways to answer the same question. The four question strategy provides a model for teachers of science to assist their students in developing their confidence to utilize scientific inquiry. The strategy begins with a testable question which can be posed by the teacher. When the class investigates the question, different groups can approach the question by testing different independent variables. As groups of students devise their procedures, they will also be deciding what data is to be collected and reported to answer the testable question. Table 2 is the result of a four question strategy that examines how the number of ice cubes influences water temperature. After formulating their responses, the students can generalize their experimental design of the question, independent and dependent variables, data table, hypothesis, conclusion based upon constant conditions that provided control (Table 3). This development is an example of students utilizing creativity to resolve a testable question.

\section{Summary}

Creativity has a place in K-12 science education in the United States. The use of the four question strategy allows students to be creative in their designing a way to solve a testable question and helps science teachers' address their frustrations about inquiry [17]. This guided inquiry experience will help students to become more comfortable in approaching science. It is also motivational because students can devise their approach, decide the type of data to be collected, and formulate a conclusion to the question. The STS movement includes creativity and can incorporate the four question plan to a local problem.

Future research could compare STS classrooms where the four question strategy has been consistently used with non-use classrooms. A qualitative case study could also investigate how groups decide which independent variable was selected to answer the problem. A series of semi-structural interviews of teachers and analysis of videos of each group could provide insight about use of the four question strategy. Students would rate their perceived level of creativity in STS unit. Science teachers

Table 2. Completed four question strategy

National Research Council. (2000). Inquiry and the National Science Education Standards. Washington, D.C.: National Academy Press. (p. 29).

Testable question: How does the number of ice cubes affect temperature of water?

1. Materials available

Number of ice cubes, thermometer, shape of ice cube, amount of water, initial water temperature, type of water, stir, container, graduated cylinder

2. Different forms of materials:

$\begin{array}{ll} & \text { Number ice cubes } \\ 1 & \\ 2 & \\ 3 & \\ 4 & \end{array}$

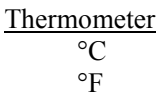

Amount of water $50 \mathrm{ml}$

$100 \mathrm{ml}$

$150 \mathrm{ml}$

$200 \mathrm{ml}$

Type of water

tap

distilled

bottled
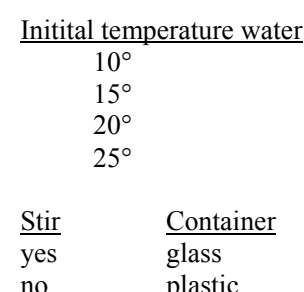

no

$$
\begin{aligned}
& \text { Container } \\
& \text { glass } \\
& \text { plastic }
\end{aligned}
$$

metal

styrofoam
Shape of ice cube

Rectangle

Circle

Crushed

Half moon

Square

Cylinder

Time

1 minute

2 minutes

3 minutes

$\underline{\text { Graduated cylinder }}$

$10 \mathrm{ml}$

$25 \mathrm{ml}$

$50 \mathrm{ml}$

$100 \mathrm{ml}$

3. What is to be modified?

Number of ice cubes

4. How will its impact be measured?

${ }^{\circ} \mathrm{C}$ 
Table 3. Experimental design for testing how the number of ice cubes affects water temperature

Title: The Effect of the Number of Ice Cubes on the Temperature of Water

Hypothesis: If more rectangular ice cubes are used, then it will lower water temperature faster.

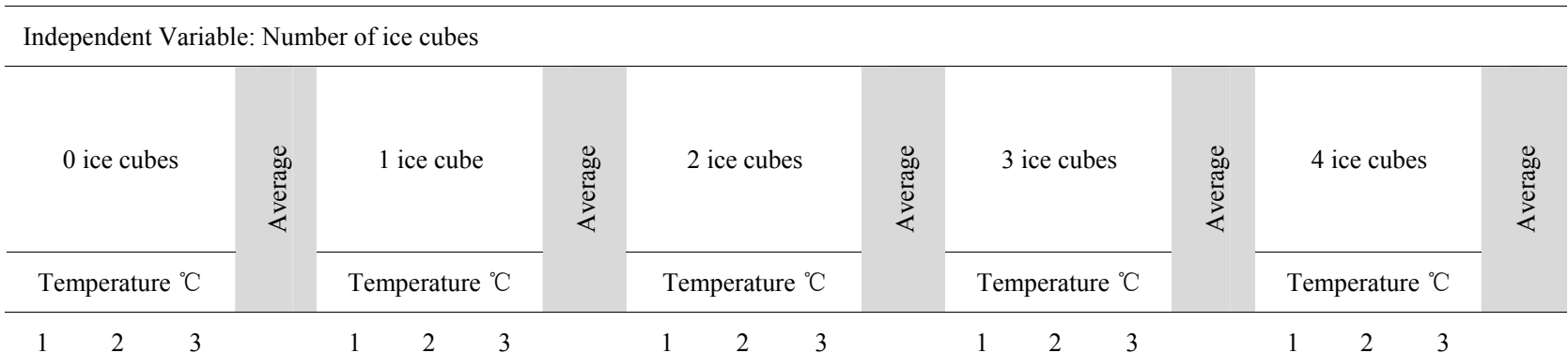

Dependent Variable: Ice water temperature in ${ }^{\circ} \mathrm{C}$

\begin{tabular}{lllll} 
Constants: & $100 \mathrm{ml}$ Tap Water & Room Temperature Water & 2 Minutes & Away from air vent and sunshine \\
Shape ice cubes & Plastic Tumbler & $0^{\circ} \mathrm{C}$ & No Stir & \\
\hline
\end{tabular}

would note the level of creativity of individual students. Correlations could be computed between teacher's rating with individual students. Science teachers would selfcategorize their teaching on each of the five aspects of inquiry [19].

\section{REFERENCES}

[1] J. Cothron, R. Giese and R. Rezba, "Science Experiments and Projects for Students," Kendall-Hunt Publishing Company, Dubuque, 2006.

[2] P. Kind and V. Kind, "Creativity in Science Education: Perspectives and Challenges for Developing School Science," Studies in Science Education, Vol. 43, No. 1, 2007 , pp. 1-37.

[3] R. Root-Berstein and M. Root-Bernstein, "Artistic Scientists and Scientific Artists: The Link between Polymathy and Creativity," In: R. Sterberg, et al., Ed., Creativity from Potential to Realization, American Psychological Association, Washington, D.C., 2004, pp. 127-151.

[4] C. Snow, "The Two Cultures and the Scientific Revolution," Cambridge University Press, London, 1959.

[5] M. Cschszentmihalyi, K. Rothende and D. Whalen, "Talented Teenagers," Cambridge University Press, Cambridge, 1993.

[6] D. Mosley, et al., "Framework for Thinking," Cambridge University Press, Cambridge, 2005.

[7] M. Runco, "Creativity," Annual Review of Psychology, Vol. 55, 2004, pp. 657-687.

[8] H. Gardner, "Multiple Intelligences," Basic Books, Inc., New York, 2006.
[9] M. Csikszentmihalyi, "Creativity," HarperCollins, New York, 1996.

[10] J. Nakaimura and M. Czekozenbmchalji, "Catalytic Creativity: The Case of Linus Pauling," American Psychologist, Vol. 56, No. 4, 2001, pp. 337-341.

[11] M. Plucker, et al., "Why isn't Creativity More Important to Educational Psychologists? Potential Pitfalls and Future Directions in Creativity Research," Educational Psychology, Vol. 39, No. 2, 2004, pp. 83-96.

[12] M. Plucker, "A 100 Year Review of Creativity Research," A paper presented at the International Creativity Education Conference, Ksionong, Taiwan, 24 October 2008.

[13] H. Gardner, "Frames of Mind," Basic Books, Inc., New York, 1983.

[14] V. John-Steiner, "Notebooks of the Mind," University of New Mexico Press, Albuquerque, 1985, pp. 203-204.

[15] A. Koestler, "The Act of Creation," Macmillan, New York, 1964.

[16] National Research Council, "National Science Education Standards," National Academy Press, Washington, D.C., 1996.

[17] D. Taylor, M. Jones, B. Broadwell and T. Oppewal, "Creativity, Inquiry, or Accountability? Scientists' and Teachers' Perceptions of Science Education," Science Education, Vol. 92, No. 6, 2008, pp. 1058-1075.

[18] D. Hodson and D. Reid, "Science for All-Motives, Meaning and Implications," School Science Review, Vol. 69, No. 249, 1988, pp. 653-661.

[19] R. Yager and A. McCormack, “Assessing Teaching/ Learning Success in Multiple Domains of Science and Science Education," Science Education, Vol. 73, No. 1, 
1989, pp. 45-58.

[20] R. Yager and R. Roy, "STS: Most Persuasive and Most Radical of Your Approaches to Science Education," In: R. Yager, Ed., What Research Says to Science Teachers, National Science Teachers Association, Washington, D.C., Vol. 7, 1993, pp.7-16.

[21] R. Yager, "Science-Technology-Society as Reform," School Science \& Mathematics, Vol. 93, No. 3, 1993, pp. 145-151.

[22] J. Penick, "Creativity and the Value of Questioning in STS," In: R. Yager, Ed., Science/Technology/Society: As Reform in Science Education, State University of New York Press, Albany, 1996, pp. 84-94.

[23] M. Lee and I. Erdogan, "The Effect of Science Technology Society Teaching on Students' Attitude toward Science and Certain Aspects of Creativity," International Journal of Science Education, Vol. 29, No. 11, 2007, pp. 1315-1327.

[24] American Association for the Advancement of Science, "Science for all Americans," Author, Washington, D.C.,
1989.

[25] L. Barrow, "A Brief History of Inquiry-from Dewey to Standards," Journal of Science Teacher Education, Vol. 17, No. 3, 2006, pp. 265-278.

[26] National Research Council, "Inquiry and National Science Education Standards," National Academy Press, Washington, D.C., 2000, p. 29.

[27] J. Swaab, "The Teaching of Science as Inquiry," In: J. Swaab and P. Brandwein, Eds., Teaching of Science, Howard University Press, Cambridge, 1962, pp. 1-103.

[28] A. Coburn, “An Inquiry Primer," Science Scope, Vol. 23, No. 6, 2000, pp. 42-49.

[29] J. Settlage, "Demythologizing Science Teacher Education: Conquering the False Ideal of Open Inquiry," Journal of Science Teacher Education, Vol. 18, No. 4, 2007, pp. 461-467.

[30] A. Johnston, "Demythologizing or Dehumanizing: A Response to Settlage and the Ideals of Open Inquiry," Journal of Science Teacher Education, Vol. 19, No. 1, 2008, pp. 11-13. 